\title{
Comparison of cryptobenthic reef fish communities among microhabitats in the Red Sea
}

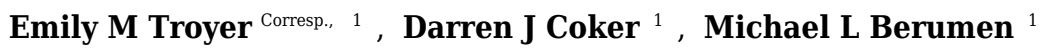 \\ ${ }^{1}$ Red Sea Research Center, Division of Biological and Environmental Sciences and Engineering, King Abdullah University of Science and Technology, \\ Thuwal, Saudi Arabia \\ Corresponding Author: Emily M Troyer \\ Email address: emily.troyer@kaust.edu.sa
}

Knowledge of community structure within an ecosystem is essential when trying to understand the function and importance of the system and when making related management decisions. Within the larger ecosystem, microhabitats play an important role by providing inhabitants with a subset of available resources. On coral reefs, cryptobenthic fishes encompass many groups and make up an important proportion of the biodiversity. However, these fishes are relatively small, exhibit extreme visual or behavioral camouflage, and, therefore, are often overlooked. We examined the differences in fish community structure between three common reef microhabitats (live hard coral, dead coral rubble, and sand) using ichthyocide stations in the central Red Sea. Using a combination of morphological and genetic (COI barcoding) techniques, we identified 326 individuals representing 73 species spread across 17 families, from fifteen $1 \mathrm{~m}^{2}$ quadrats. Fish assemblages in the three microhabitats were significantly different from each other. Rubble microhabitats yielded the highest levels of fish abundance, richness, and diversity, followed by hard coral, and then sand. The results show benthic composition, even at a small scale, influences cryptobenthic communities. This study also provides new COI sequence data to public databases, in order to further the research of cryptobenthic fish in the Red Sea region. 
1 Comparison of cryptobenthic reef fish communities among microhabitats in the Red Sea

2

3 Short title: Red Sea cryptobenthic fishes

4

5 Emily M. Troyer ${ }^{1 *}$, Darren J. Coker ${ }^{1}$, Michael L. Berumen ${ }^{1}$

6

$7 \quad{ }^{1}$ Red Sea Research Center, Division of Biological and Environmental Sciences and Engineering,

8 King Abdullah University of Science and Technology, Thuwal 23955-6900, Saudi Arabia

9

$10 *$ corresponding author: emily.troyer@kaust.edu.sa

11

12

13

14

15

16

17

18

19

20

21 


\section{ABSTRACT}

23 Knowledge of community structure within an ecosystem is essential when trying to understand

24 the function and importance of the system and when making related management decisions.

25 Within the larger ecosystem, microhabitats play an important role by providing inhabitants with

26 a subset of available resources. On coral reefs, cryptobenthic fishes encompass many groups and

27 make up an important proportion of the biodiversity. However, these fishes are relatively small,

28 exhibit extreme visual or behavioral camouflage, and, therefore, are often overlooked. We

29 examined the differences in fish community structure between three common reef microhabitats

30 (live hard coral, dead coral rubble, and sand) using ichthyocide stations in the central Red Sea.

31 Using a combination of morphological and genetic (COI barcoding) techniques, we identified

32326 individuals representing 73 species spread across 17 families, from fifteen $1 \mathrm{~m}^{2}$ quadrats.

33 Fish assemblages in the three microhabitats were significantly different from each other. Rubble

34 microhabitats yielded the highest levels of fish abundance, richness, and diversity, followed by

35 hard coral, and then sand. The results show oenthic composition, even at a small scale,

36 influences cryptobenthic communities. This study also provides new COI sequence data to

37 public databases, in order to further the research of cryptobenthic fishes in the Red Sea region. 


\section{INTRODUCTION}

40 Habitat influences species abundances and distribution patterns in a range of ecosystems (Venier

41 \& Fahrig, 1996; Warren et al., 2001). Microhabitats on coral reefs, such as areas dominated by

42 living hard corals, soft corals, rubble patches, macroalgae, or sandy areas, can offer a range of

43 resources such as food and shelter for small fishes (Beukers \& Jones, 1997; Depczynski \&

44 Bellwood, 2004; Brooker, Munday \& Ainsworth, 2010; Coker et al., 2014). Corals provide

45 refuge spaces within the branches (Robertson \& Sheldon, 1979), while the colony itself can

46 provide shelter underneath for larger fishes (Kerry \& Bellwood, 2012). It is expected that small

47 and benthic-associated fishes would be influenced greatly by available habitats, and, therefore,

48 understanding microhabitat requirements is essential for reef fishes.

49 On coral reefs, there are many groups of fishes that are relatively small $(<50 \mathrm{~mm})$, have

50 a close association with the substrate, and have a cryptic nature (Depczynski \& Bellwood, 2003).

51 These fishes, termed "cryptobenthic reef fishes", can be behaviorally cryptic by seeking out

52 cracks and crevices in the reef in which to hide, or they can be visually cryptic, having coloration

53 that matches the substrate where they live (Depczynski \& Bellwood, 2003; Goatley \& Brandl,

54 2017). Fast-growing and with naturally short lifespans, these fishes are an important functional

55 group on coral reefs (Depczynski \& Bellwood, 2006). Microhabitat preferences have been well

56 studied in blennies (Wilson, 2001; Gonçalves \& Faria, 2009) as well as gobies (Munday, Jones

57 \& Caley, 1997; Munday et al., 2002). Their small size, coupled with small home ranges

58 (Luckhurst and Luckhurst 1978), has enabled them to make use of a multitude of different

59 microhabitats.

60 Despite their functional importance, cryptobenthic fishes are difficult to sample due to

61 their cryptic nature and, therefore, relatively understudied worldwide. When compared to other 
62 methods, visual surveys underestimate the number of cryptobenthic species on a reef (Ackerman

$63 \&$ Bellwood, 2000; Robertson \& Smith-Vaniz, 2008). Most surveys ignore them due to logistical

64 and taxonomic difficulties. Thus, more targeted surveying techniques have recently been

65 employed in order to gain a more accurate count of cryptobenthic reef fishes. Chemical

66 ichthyocides, such as rotenone and clove oil, are an effective tool to collect small fishes, and

67 reveal more cryptic species when compared to traditional visual surveys (Brock, 1982).

A majority of cryptobenthic fish studies have arisen from well-studied areas, such as the

69 Great Barrier Reef and the Caribbean (see Ackerman \& Bellwood, 2000, 2002; Harborne et al.,

70 2012, Goatley, González-Cabello \& Bellwood, 2016), but an important region that is greatly

71 understudied is the Red Sea (Berumen et al., 2013). The Red Sea is a unique environment, with

72 higher average temperatures and salinity compared to other regions (Edwards, 1987). It is

73 recognized as a biodiversity hotspot, with an estimated $14 \%$ of fish species in the Red Sea

74 endemic to the region (DiBattista et al., 2016). Recent studies in this region show that

75 cryptobenthic fish communities differ latitudinally, with distance from shore, and that habitat

76 may be a driving factor (Coker et al., 2018).

77 This study aims to explore small-scale differences in the community composition of

78 cryptobenthic reef fishes associated with three common reef microhabitats. Live hard corals,

79 rubble patches, and sandy areas all represent habitats that cryptobenthic fishes are known to

80 utilize (Depczynski \& Bellwood, 2004; Ahmadia et al., 2012; Tornabene et al., 2013).We

81 hypothesize that cryptobenthic fish assemblages will significantly differ between these three

82 microhabitats. The information gathered will begin to build a preliminary framework of Red Sea

83 cryptobenthic fish ecology and provide much needed data, as well as vouchered samples, for

84 these understudied fishes. 
MATERIALS AND METHODS

\section{$87 \quad$ Study site}

88 Fishes were sampled in May 2017 during daylight hours from the southern portion of Al Fahal reef situated in the middle of the continental shelf $\left(22^{\circ} 13.6558 \mathrm{~N}, 38^{\circ} 58.1853 \mathrm{E}\right)$ (Fig. $\left.1 \mathrm{~A}\right)$. Sampling was conducted between 10-15 m depth (majority of stations between 12-13 m) (Table S1). This single reef and narrow depth range were selected to minimize any potential environmental variables, such as temperature, wave energy, current, and turbidity that could be introduced if sampling in varying parts of the reef (e.g., sides exposed to or sheltered from dominant wave action).

\section{Microhabitats}

97 Quadrats $\left(1 \mathrm{~m}^{2}\right)$ constructed from PVC pipe (see Fig. 1) were placed onto a flat or gently sloping 98 surface $\left(<10^{\circ}\right)$ of the reef in one of the three targeted microhabitats. Three microhabitat types

99 were sampled: live hard coral, dead coral rubble, and sand (Fig. 1 B-D). For each microhabitat

100 type, five replicate quadrats were sampled. Hard coral microhabitats were defined as having at

101 least $70 \%$ of the survey quadrat covered with hard coral, with the remaining area composed of

102 other microhabitat components, as seen from an aerial view. Tabular Acropora species were 103 targeted for consistency. Rubble microhabitats contained at least 50\% coverage of dead hard

104 coral rubble, rocks, and/or empty shells. Sand microhabitats contained at least $90 \%$ coverage of

105 sand with little or no rubble mixed in (Table S1). Each quadrat was placed at least 1-2 meters 106 away from a neighboring microhabitat type. Percent cover of each microhabitat category was

107 calculated using a grid point system. A 10 x10 grid (i.e., 100 total intercepting points) was 
108 overlaid onto a digital image of each quadrat. Each point in the image was categorized into the

109 above microhabitat type to produce at percent cover. Rugosity of the sample quadrat was

110 measured as a linear distance using a $1 \mathrm{~m}$ chain (sensu Risk, 1972).

111

\section{Fish communities}

113 An ichthyocide (rotenone) was used to collect fish due to its high success rate in targeting cryptic

114 species (Robertson \& Smith-Vaniz, 2008). A rotenone mixture was prepared by mixing $500 \mathrm{~g}$ of

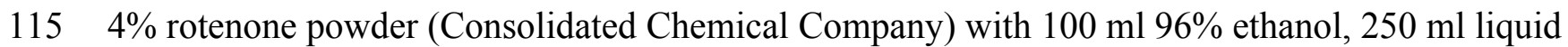

116 dishwashing detergent, and $100 \mathrm{ml}$ water (adapted from Ackerman \& Bellwood, 2000).

117 A $4 \mathrm{~mm}$ mesh net weighted down with chain was placed around the quadrat, enclosing

118 the whole area. The rotenone mixture was gently squirted into the netted area until the whole

119 area was covered. After waiting about five minutes for the rotenone to take effect, the net was

120 removed and fishes were collected using hand nets and tweezers (following Ackerman \&

121 Bellwood, 2000). Because some fish were observed escaping the enclosed quadrat (either

122 through the reef matrix or net) while the rotenone took effect, all deceased fishes directly around

123 the sample area were collected for consistency. Water flow across the quadrats was minimal

124 during ichthyocide deployment. Therefore, the effects were restricted primarily to within the

125 sample area. However, we cannot discount some individuals outside the area succumbing to

126 drifting rotenone. In these cases, the small number would have minimal influence in overall

127 community composition. After collecting the visible fishes, three divers intensively searched

128 within each quadrat by lifting up any loose rubble or debris where hidden fishes could have

129 settled. Quadrats were searched until no new fishes were found for a period of five minutes.

130 Larger predatory fishes that came too close to the quadrat were chased away before they could 
131 consume any of the asphyxiated fishes.

132 Immediately after the dive, collected fishes were placed into an ice slurry to preserve

133 coloration for photography (within $\sim 2 \mathrm{hrs}$.). Once photographed, fishes were placed into

134 individual labeled vials containing a solution of $96 \%$ ethanol for preservation. A tissue sample

135 (pectoral or caudal fin) was collected from each individual for genetic analysis.

136 Fish sampling was done in accordance with the guidelines and procedures approved

137 under the auspices of the King Abdullah University of Science and Technology (KAUST)

138 Institutional Animal Use and Care Committee (IACUC) under approval number 17-04-004.

\section{Genetic fish identification}

141 Tissue samples were cleaned with $96 \%$ ethanol and gently patted dry before placed into 96-well

142 plates containing $100 \mu \mathrm{l} 50 \mathrm{mM} \mathrm{NaOH}$. DNA was extracted from the samples using the

143 HotSHOT protocol $\left(95^{\circ} \mathrm{C}\right.$ for 20 minutes, $4{ }^{\circ} \mathrm{C}$ for 10 minutes) (Meeker et al., 2007). After

144 extraction, $10 \mu \mathrm{l}$ of $1 \mathrm{M}$ Tris-Hcl (10\%) was added to each well and mixed with pipettes.

$14580 \mu \mathrm{l}$ from each sample was transferred to a new plate for DNA amplification. A

146 polymerase chain reaction (PCR) Qiagen Multiplex Mastermix containing Taq polymerase,

$147 \mathrm{dNTPs}, \mathrm{MgCl}_{2}$, and reaction buffers was added to each well. Primers COI Universal Fish R2 5'

148 ACT TCA GGG TGA CCG AAG AAT CAG AA 3' and F2 5' TCG ACT AAT CAT AAA GAT

149 ATC GGC AC 3' (Ward et al., 2005) were used to amplify the COI region of DNA. Each PCR

150 well contained $6.25 \mu \mathrm{l}$ MasterMix, $4.25 \mu \mathrm{l}$ nuclease free water, $0.5 \mu 1$ forward primer, $0.5 \mu 1$

151 reverse primer, and $1 \mu \mathrm{DNA}$, for a total volume of $12.5 \mu \mathrm{l}$. Thermocycling occurred with an

152 initial denaturation period of 15 minutes at $95^{\circ} \mathrm{C}$, followed by 35 cycles of 30 seconds at $94{ }^{\circ} \mathrm{C}$,

15360 seconds at the annealing temperature of $45^{\circ} \mathrm{C}$, and 60 seconds at $72{ }^{\circ} \mathrm{C}$, followed by a final 
154 extension period of 10 minutes at $72^{\circ} \mathrm{C}$. PCR products were visualized using a QIAxcel system.

155 Following PCR amplification, $2.14 \mu \mathrm{l}$ ExoStar was added to each well to clean the PCR product.

156 The mixture was incubated in the thermocycler for 60 minutes at $37^{\circ} \mathrm{C}$, then 15 minutes at $85{ }^{\circ} \mathrm{C}$.

157 Cleaned PCR products were sequenced via Sanger sequencing via ABI 3730xl sequencers in the

158 KAUST Bioscience Core Lab.

159 In the event that a sample sequence did not yield a long enough strand of base pairs to be

160 entered into a database ( $\sim 500 \mathrm{bp})$, DNA was extracted again using a more precise Qiagen

161 DNeasy Blood and Tissue kit. The PCR process was then repeated on those samples.

162 After sequencing was completed, sample sequences were checked against several

163 sequence databases for potential matches. The National Center for Biotechnology Information

164 (NCBI) GenBank (https://www.ncbi.nlm.nih.gov/genbank) and Barcode of Life Data System

165 (BOLD) (http://www.boldsystems.org) were used as public databases. A custom (in-house) Red

166 Sea fish sequence database was also checked (see DiBattista et al., 2017; Isari et al., 2017; Coker

167 et al., 2018). A sequence was considered a good match for a species in the database if the

168 matched sequence was $98 \%$ similar or higher. However, some species of cryptobenthic fishes

169 can differ by fewer than 2\% COI similarity (e.g. Greenfield and Tornabene, 2014; Tornabene et

170 al., 2015). Sequence matches were then checked against visual guides and morphological keys to

171 double-check identity. In the event of a non-matching sequence, a sample was identified to

172 species level, or as close as possible, with the use of keys that examined morphological features.

173 When a species was unable to be identified using the aforementioned methods, it was assigned

174 an operational taxonomic unit (OTU) so as to still be included in the data analysis. OTUs were

175 named for previously uploaded sequences in the databases if there was a match. In the event a

176 sequence did not match a previously assigned OTU within one of the databases, a new OTU was 
177 assigned. COI sequences for sequenced species, including new OTUs, are deposited to GenBank

178 under ascension numbers MG583518-MG583524 and MH160733-MH160761.

180 Morphological fish identification

181 With the use of keys, fishes that could not be identified genetically were assigned to a species,

182 genus, or family level. The typical morphological characters that were useful in discriminating

183 taxa included: counts of fin spines and soft rays, pelvic fin structure, cephalic pore counts, lateral

184 line scale counts, as well as general meristics. Morphological characters were assessed using

185 light dissection microscopy and an online image analysis tool for measuring morphometrics

186 (Froese \& Pauly, 2017). For a list of keys used, see Appendix 1.

187

188 Community analysis

189 Species richness was defined as the number of species or OTUs identified from each quadrat.

190 Diversity (Shannon's diversity index, $\mathrm{H}^{\prime}$ ) was calculated using the following formula: $\mathrm{H}^{\prime}=-\sum p \mathrm{i}$

$191 \ln (p \mathrm{i})$ (Shannon \& Weaver, 1963), and then subsequently averaged within each microhabitat

192 type. Analysis of variance (ANOVA) was used to compare species richness, abundance, and

193 diversity among habitat treatments. Significant pairings were identified using a post-hoc Tukey

194 test. Fish communities present at each microhabitat type were plotted using non-metric

195 multidimensional scaling (nMDS) using a square root transformation and Bray-Curtis

196 resemblance matrix. A hierarchical cluster analysis was used to further illustrate the differences

197 between microhabitat types. Permutational analysis of variance (PERMANOVA) was used to

198 analyze fish community differences among microhabitats. A permutational analysis of

199 multivariate dispersions (PERMDISP) test was preformed to test for homogeneity of dispersions 
200 between microhabitat clusters. The dispersion within the three microhabitats did not differ

201 significantly in all fish (PERMDISP, $\mathrm{F}_{2,12}=2.67, \mathrm{p}=0.217$ ), or in gobies (PERMDISP, $\mathrm{F}_{2,10}=3.94$,

$202 \mathrm{p}=0.116)$. However, pairwise comparisons between microhabitat types for all fish differed

203 significantly between coral and rubble (PERMDISP, $\mathrm{p}=0.038$ ), and between rubble and sand in

204 all gobies (PERMDISP, $\mathrm{p}=0.008$ ). A similarity percentage (SIMPER) analysis was conducted to

205 identify which fish species contributed most to the differences between microhabitats. Analyses

206 were conducted with R version 3.4.0 (R Core Team, 2017), (vegan package - Oksanen et al.,

207 2017), and PRIMER-e v6 (Clarke \& Gorley, 2006).

208

209 RESULTS

210 Fish communities

211 A total of 326 individuals representing 73 species and 17 families were collected from three

212 microhabitat types (Table S2). The total number of all fishes collected at each quadrat ranged

213 from 1 to 65 . Rubble had the highest average numbers of fish abundance (ANOVA $F_{2,12}=11.59$,

$214 \mathrm{p}=0.002)$ and species richness $\left(\mathrm{F}_{2,12}=6.78, \mathrm{p}=0.011\right)$, followed by coral, and then sand (Fig. 2).

215 Diversity did not have a significant effect among microhabitats $\left(F_{2,12}=2.80, p=0.10\right)$.

216 Quadrats that were associated with the same microhabitat type grouped more closely

217 together than unrelated microhabitat types (Fig. 3). Fish communities in all three microhabitats

218 differed significantly (PERMANOVA $\mathrm{F}_{2,12}=2.63$, $\mathrm{p}<0.001$ ) (Fig. 3A) with significant

219 differences detected between coral and rubble $(\mathrm{p}=0.006)$, coral and sand $(\mathrm{p}=0.008)$, and rubble

220 and sand $(\mathrm{p}=0.012)$. The dendrogram of the cluster analysis supports the nMDS by showing the

221 groupings of the three microhabitat types sampled (Fig. 3C). Coral and rubble microhabitats are

222 more similar to each other than to the sand microhabitats (Fig. 3C-D). 
224 Goby communities

225 Out of the 326 fish collected, family Gobiidae comprised the majority, with a total of 232

226 individuals (71.1\%) collected, representing 31 species. On average, rubble communities had the

227 highest levels of goby abundance (ANOVA $\left.\mathrm{F}_{2,12}=24.61, \mathrm{p}<0.001\right)$, species richness $\left(\mathrm{F}_{2,12}=14.95\right.$, $228 \mathrm{p}<0.001)$, and diversity $\left(\mathrm{F}_{2,12}=5.10, \mathrm{p}=0.025\right)$, followed by coral communities, and then sand 229 communities (Fig. 2). Abundance ranged from 0 to 46 gobies per quadrat. The most abundant 230 goby was Trimma avidori, with a total of 44 individuals collected in both coral and rubble 231 microhabitats. The second most abundant goby was Callogobius bifasciatus, with 29 individuals 232 collected in mainly rubble quadrats (Fig. 4). Of 31 goby species collected, 11 species (35.4\%) 233 were represented by only a single individual. The majority of species $(64.5 \%)$ had fewer than 5 234 individuals collected.

235 Overall, goby community composition significantly differed among microhabitats 236 (PERMANOVA $\mathrm{F}_{2,12}=3.67, \mathrm{p}<0.001$ ) (Fig. 3B), with more similar microhabitats grouping 237 together (Fig. 3D). Pairwise comparisons between microhabitats show significant differences 238 between coral and rubble $(\mathrm{p}=0.01)$, coral and sand $(\mathrm{p}=0.03)$, and rubble and sand $(\mathrm{p}=0.007)$.

239 Gobies C. bifasciatus, Asterropteryx semipunctata, T. avidori, and Eviota zebrina contributed

240 the most to the differences found between rubble and sand microhabitats (average contributions

$24112.58 \%, 12.53 \%, 8.55 \%$, and $6.42 \%$, respectively) (Table 1). These four species are also the

242 highest contributors to differences found between coral and rubble microhabitats (cumulative 243 contribution 30.54\%). Between coral and sand microhabitats, Pleurosicya prognatha and 244 Istigobius decoratus were the highest contributors (10.94\% and 7.73\%), with T. avidori 245 following close behind (5.77\%). 


\section{DISCUSSION}

248 This study offers insight into the scale at which cryptobenthic fishes may be influenced by

249 habitat characteristics in the Red Sea. Within one reef, we found community differences among

250 three microhabitats. Overall, there is evidence that rubble habitats support a greater number of

251 individuals and species of cryptobenthic fishes. However, live coral and sand habitats may be

252 important for more specialist species. Therefore, the majority of this group may depend on the

253 fine scale complexity of the reef rather than benthic cover per se. The Red Sea has high rates of

254 biodiversity and endemism (DiBattista et al., 2016), and this was also reflected in the relatively

255 unexplored cryptobenthic communities with 73 species collected, of which 17 are endemic to the

256 Red Sea (Table S2).

257 Cryptobenthic fishes have many habitat preferences and can be specialized or generalized

258 to live in certain microhabitats. Food type and availability are possible drivers of specialization

259 or generalization with this group. Certain gobies, like Bryaninops natans and Pleurosicya

260 prognatha, were found primarily in coral dominated habitats. These fish are highly adapted

261 coral-obligates and depend solely upon live corals and coral mucus for food (Herler 2007; Herler,

262 Koblmuller \& Sturmbauer, 2009). Other fish, like Eviota distigma, were found in almost equal

263 abundances across all three microhabitat types. Many Eviota spp. are broad habitat generalists,

264 choosing to live in a variety of habitats (Depczynski \& Bellwood, 2004; Herler, Munday \&

265 Hernaman, 2011). They feed mainly upon small invertebrates, such as copepods, (Greenfield,

266 2017) that can be found across a wide variety of microhabitat types (Preston \& Doherty, 1994;

267 Stella, Jones \& Pratchett, 2007).

268 The architecture provided by physical structures within each microhabitat provides 
269 negative spaces of different sizes that are likely to have an influence on the presence and 270 abundance of cryptobenthic fishes. Highly complex areas offer a means to avoid and escape

271 larger predators (Beukers \& Jones, 1997). The importance of complex habitats is evident by

272 positive correlations with the abundances of conspicuous fishes (Caley \& St John, 1996;

273 Friedlander \& Parrish, 1998), and cryptobenthic fishes (Depczynski \& Bellwood, 2004). High

274 complexity, as measured by rugosity, was found in coral quadrats; however, this course scale is

275 likely more important for larger fishes than for cryptobenthics. Despite the coral microhabitats

276 having very high complexity, they did not have the highest abundance levels. Rubble

277 microhabitats had extremely high fish abundances, suggesting that measuring rugosity on a

278 broad scale may not be relevant for small, cryptic fishes. Instead, small, intricately laid pieces of

279 rubble, may offer enough shelter from predators for tiny fishes, and prove more important to 280 their survival than live coral or sand habitats.

281 In addition to investigating habitat associations, this study helps build on the limited

282 available information about this group through collected specimens. These provide sequence data 283 and vouchered specimens for many unknown Red Sea species, an effort that will undoubtedly 284 assist future studies within the region. This study provides genetic sequences of species/OTUs 285 for the Red Sea along with photographs. However, of all the fish collected, 84 (25.7\%) could not 286 be confidently assigned to species level using either morphological or genetic techniques. One 287 candidate for new species was identified from these OTUs, and is currently being assessed by 288 expert taxonomists. These difficulties associated with identifying cryptobenthic fishes highlight 289 the need for a comprehensive sequence library that includes reference images, as well as for 290 more cryptobenthic taxonomists actively describing new species.

291 While this study was limited in scale, differences were observed in cryptobenthic fish 
292 communities among habitats at the scale of a reef site. Species accumulation curves (Fig. S1)

293 suggest that increased sampling (spatially and replication) would yield more unique species.

294 However, we expect the observed patterns among habitats to hold. Furthermore, we only

295 investigated three common reef habitats, whereby countless more exist (e.g., soft coral, seagrass,

296 depth, exposure), and in a gradient of combinations. Given their intimate relationship with the

297 benthos at a small scale, we expect that communities would differ among most habitats driven by

298 species with more specialist resource requirements. For consistency, this study targeted coral

299 microhabitats containing Acropora spp. Given fishes can have species-specific coral

300 relationships (Munday, Jones \& Caley, 1997; Munday, 2002), habitats containing other coral

301 species and morphologies would also significantly influence the presence/absence and

302 abundance of some species. Surprisingly, three Gobiodon individuals and one P. prognatha

303 individual were collected from a sand habitat, despite being known coral-obligate species (Herler,

304 2007). While live coral was not present in these habitats, we postulate that these originated from

305 nearby live corals as a result of drifting rotenone in the water column and diver disturbance.

306 Despite this, we still find clear differences among microhabitats.

307 This study is one of the few to examine microhabitat associations of cryptobenthic fishes

308 in the Red Sea. These fishes are undoubtedly an important functional group, but they may hold

309 more importance to the Red Sea ecosystem. Higher temperatures increase growth rates as well as

310 shorten larval duration times among coral reef fishes (Green \& Fisher, 2004). This effect would

311 most likely be multiplied in cryptobenthic fishes due to their already fast growth rates and short

312 lifespans (Depczynski \& Bellwood, 2006). In the Red Sea, which is warmer than other bodies of

313 water (Edwards, 1987), cryptobenthic fishes would most likely have higher turnover rates and be

314 able to contribute more to the food web, than their counterparts in other areas of the ocean. 


\section{ACKNOWLEDGEMENTS}

318 The authors would like to thank Michael Campbell for his mapmaking expertise, as well as

319 Calder Atta, Royale Hardenstine, Alison Monroe, Tullia Terraneo, Matthew Tietbohl, and Sara

320 Wilson for their assistance in the field. We are also grateful to Calder Atta, Simon Brandl, and

321 Luke Tornabene for their help in identifying several fish species. Fieldwork was supported by

322 the KAUST Coastal and Marine Resources Core Laboratory. Feedback from Christopher

323 Goatley and Luke Tornabene greatly improved the manuscript. 


\section{REFERENCES}

325

326 Ackerman JL, Bellwood DR (2000) Reef fish assemblages: a re-evaluation using enclosed rotenone stations. Mar Ecol Prog Ser 206:227-237

Ackerman JL, Bellwood DR (2002) Comparative efficiency of clove oil vs rotenone for sampling tropical reef fish assemblages. J Fish Biol 60:893-901

330

331

332

333

334

335

336

337

338

339

340

341

342

343

344

345

346

Ahmadia, GN, Pezold FL, Smith DJ (2012) Cryptobenthic fish biodiversity and microhabitat use in healthy and degraded coral reefs in SE Sulawesi, Indonesia. Mar Biodivers 42:433-442

Berumen ML, Hoey A, Bass W, Bouwmeester J, Catania D, Cochran JE, Khalil MT, Miyake S, Mughal MR, Spaet J (2013) The status of coral reef ecology research in the Red Sea. Coral Reefs 32:737-748

Beukers JS, Jones GP (1997) Habitat complexity modifies the impact of piscivores on a coral reef fish population. Oecologia 114:50-59.

Brock RE (1982) A critique of the visual census method for assessing coral reef fish populations. B Mar Sci 32:269-276

Brooker RM, Munday PL, Ainsworth TD (2010) Diets of coral-dwelling fishes of the genus Gobiodon with evidence of corallivory. J Fish Biol 76:2578-2583

Caley JM, St John J (1996) Refuge availability structures assemblages of tropical reef fishes. J Anim Ecol 65:414-428

Clarke KR, Gorley RN (2006) PRIMER v6: User Manual/Tutorial. PRIMER-e, Plymouth, 192 $\mathrm{pp}$

Coker DJ, DiBattista JD, Sinclair-Taylor TH, Berumen ML (2018) Spatial patterns of cryptobenthic coral-reef fishes in the Red Sea. Coral Reefs DOI:10.1007/s00338-017- 
348 Coker DJ, Wilson SK, Pratchett MS (2014) Importance of live coral habitats for reef fishes. Rev Fish Biol Fisher 24:89-126

Depczynski M, Bellwood DR (2003) The role of cryptobenthic reef fishes in coral reef trophodynamics. Mar Ecol Prog Ser 256:183-191

352 353

Depczynski M, Bellwood DR (2004) Microhabitat utilisation patterns in cryptobenthic coral reef fish communities. Mar Biol 145:455-463

Depczynski M, Bellwood DR (2006) Extremes, plasticity, and invariance in vertebrate life history traits: insights from coral reef fishes. Ecology 87: 3119-3127

DiBattista JD, Roberts MB, Bouwmeester J, Bowen BW, Coker DJ, Lozano-Cortes DF, Choat JH, Gaither MR, Hobbs JPA, Khalil MT, Kochzius M, Myers RF, Paulay G, Robizch VSN, Saenz-Agudelo P, Salas E, Sinclair-Taylor TH, Toonen RJ, Westneat MW, Williams ST, Berumen ML (2016) A review of contemporary patterns of endemism for shallow water reef fauna in the Red Sea. J Biogeogr 43:423-439

DiBattista JD, Coker DJ, Sinclair-Taylor TH, Stat M, Berumen ML, Bunce M (2017) Assessing the utility of eDNA as a tool to survey reef-fish communities in the Red Sea. Coral Reefs DOI:10.1007/s00338-017-1618-1

Edwards FJ (1987) Climate and oceanography, Key environments: Red Sea. Pergamon Press, Oxford

Friedlander AM, Parrish JD (1998) Habitat characteristics affecting fish assemblages on a Hawaiian reef. J Exp Mar Biol Ecol 224:1-30

Froese R, Pauly D (2017) FishBase. World Wide Web electronic publication. www.fishbase.org, version $(06 / 2017)$ 
370 Goatley CHR, Brandl SJ (2017) Cryptobenthic reef fishes. Curr Biol 27:452-454

371 Goatley CHR, González-Cabello A, Bellwood DR (2016) Reef-scale partitioning of

372 cryptobenthic fish assemblages across the Great Barrier Reef, Australia. Mar Ecol Prog

$373 \quad$ Ser $544: 271-280$

374 Gonçalves EJ, Faria C (2009) Patterns of microhabitat utilization in blennies. In: Patzner R,

375 Gonçalves EJ, Hastings P, Kapoor B (eds.), The Biology of Blennies. Science Publishing,

376 Enfield, New Hampshire, pp. 405-440

377 Green BS, Fisher R (2004) Temperature influences swimming speed, growth and larval duration

378 in coral reef fish larvae. J Exp Mar Biol Ecol 299:115-132

379 Greenfield DW, Tornabene L (2014) Eviota brahmi n. sp. From Papua New Guinea, with a

380 redescription of Eviota nigriventris (Teleostei: Gobiidae). Zootaxa 3793:133-146

381 Greenfield DW (2017) An overview of the dwarfgobies, the second most speciose coral-reef fish

382 genus (Teleostei: Gobiidae: Eviota). J Ocean Sci Foundation 29:32-54

383 Harborne AR, Jelks HL, Smith-Vaniz WF, Rocha LA (2012) Abiotic and biotic controls of

384 cryptobenthic fish assemblages across a Caribbean seascape. Coral Reefs 31:977-990

385 Herler J (2007) Microhabitats and ecomorphology of coral-and coral rock-associated gobiid

386 fishes (Teleostei: Gobiidae) in the northern Red Sea. Mar Ecol 28:82-94

387 Herler J, Koblmuller S, Sturmbauer C (2009) Phylogenetic relationships of coral-associated 388 gobies (Teleostei, Gobiidae) from the Red Sea based on mitochondrial DNA data. Mar $389 \quad$ Biol 156:725-739

390 Herler J, Munday PL, Hernaman V (2011) Gobies on coral reefs. In: Patzner RA, Van Tassell JL, 391 Kovačić M, Kapoor BG (eds.), The Biology of Gobies, Enfield, NH: Science Publishers

392 Isari S, Pearman JK, Casas L, Michell CT, Curdia J, Berumen ML, Irigoien X (2017) Exploring 
the larval fish community of the central Red Sea with an integrated morphological and molecular approach. PloS ONE 12:e0182503

395 396

Kerry JT, Bellwood DR (2012) The effect of coral morphology on shelter selection by coral reef fishes. Coral Reefs 31:415-424

Luckhurst BE, Luckhurst K (1978) Diurnal space utilization in coral reef fish communities. Mar Biol 49:325-332

Meeker ND, Hutchinson SA, Ho L, Trede NS (2007) Method for isolation of PCR-ready genomic DNA from zebrafish tissues. Biotechniques 43:610

Munday PL (2002) Does habitat availability determine geographical-scale abundance of coraldwelling fishes? Coral Reefs 21:105-116

Munday PL, Jones GP, Caley MJ (1997) Habitat specialisation and the distribution and abundance of coral-dwelling gobies. Mar Ecol Prog Ser 152:227-239

Munday PL, Jones GP, Caley MJ (2001) Interspecific competition and coexistance in a guild of coral-dwelling fishes. Ecology 82:2177-2189

Munday PL, Pierce SJ, Jones GP, Larson HK (2002) Habitat use, social organization and reproductive biology of the seawhip goby, Bryaninops youngei. Mar Freshwater Res $53: 769-775$

Oksanen J, Blanchet FG, Friendly M, Kindt R, Legendre P, McGlinn D, Minchin PR, O’Hara RB, Simpson GL, Solymos P, Stevens MHH, Szoecs E, Wagner H (2017) vegan: Community Ecology Package. R package version 2.4-3. https://CRAN.R-project.org/package=vegan

Preston NP, Doherty PJ (1994) Cross-shelf patterns in the community structure of coral-dwelling Crustacea in the central region of the Great Barrier Reef. II. Cryptofauna. Mar Ecol Prog 
417 R Core Team (2017) R: A language and environment for statistical computing. R Foundation for 418 Statistical Computing, Vienna, Austria. URL https://www.R-project.org/

419 Risk MJ (1972) Fish diversity on a coral reef in the Virgin Islands. Atoll Res Bull 153:1-7

420 Robertson DR, Sheldon JM (1979) Competitive interactions and the availability of sleeping sites 421 for a diurnal coral reef fish. J Exp Mar Biol Ecol 40:285-298

422 Robertson DR, Smith-Vaniz WF (2008) Rotenone: an essential but demonized tool for assessing 423 marine fish diversity. Bioscience 58:165-170

Shannon CW, Weaver W (1963) Mathematical theory of communication. University Illinois 425 Press

Stella JS, Jones GP, Pratchett MS (2010) Variation in the structure of epifaunal invertebrate assemblages among coral hosts. Coral Reefs 29:957-973

Tornabene L, Ahmadia GN, Berumen ML, Smith DJ, Jompa J, Pezold F (2013) Evolution of microhabitat association and morphology in a diverse group of cryptobenthic coral reef fishes (Teleostei: Gobiidae: Eviota). Mol Phylogenet Evol 66:391-400

Tornabene L, Valdez S, Erdmann M, Pezold F (2015) Support for a 'Center of Origin' in the Coral Triangle: Cryptic diversity, recent speciation, and local endemism in a diverse lineage of reef fishes (Gobiidae: Eviota). Mol Phylogenet Evol 82:200-210

Venier LA, Fahrig L (1996) Habitat availability causes the species abundance-distribution relationship. Oikos 76: 564-570

Ward RD, Zemlak TS, Innes BH, Last PR (2005) DNA barcoding Australia's fish species. Philos Trans R Soc Lond B Biol Sci 360:1847-1857

438 Warren MS, Hill JK, Thomas JA, Asher J, Fox R, Huntley B, Roy DB, Telfer MG, Jeffcoate S, 
442 Wilson S (2001) Multiscale habitat associations of detrivorous blennies (Blenniidae: Salariini). 


\section{Figure 1}

\section{Example microhabitat quadrats}

Examples of $1 \mathrm{~m}^{2}$ quadrats sampled in the central Saudi Arabian Red Sea to assess cryptobenthic fish assemblages in each of three microhabitat types: live coral (indicated by purple), dead coral rubble (orange), and sand (teal). Quadrats were sampled using rotenone at 10-15 m depth. (A) Map of study site, with reef habitat indicated in grey; (B) Coral quadrat; (C) Rubble quadrat; (D) Sand quadrat. (Photographs taken by EMT. Map created in ArcMap, version 10.3, by Michael Campbell using various mapping sources freely available through ESRI (Environmental Systems Research Institute)).

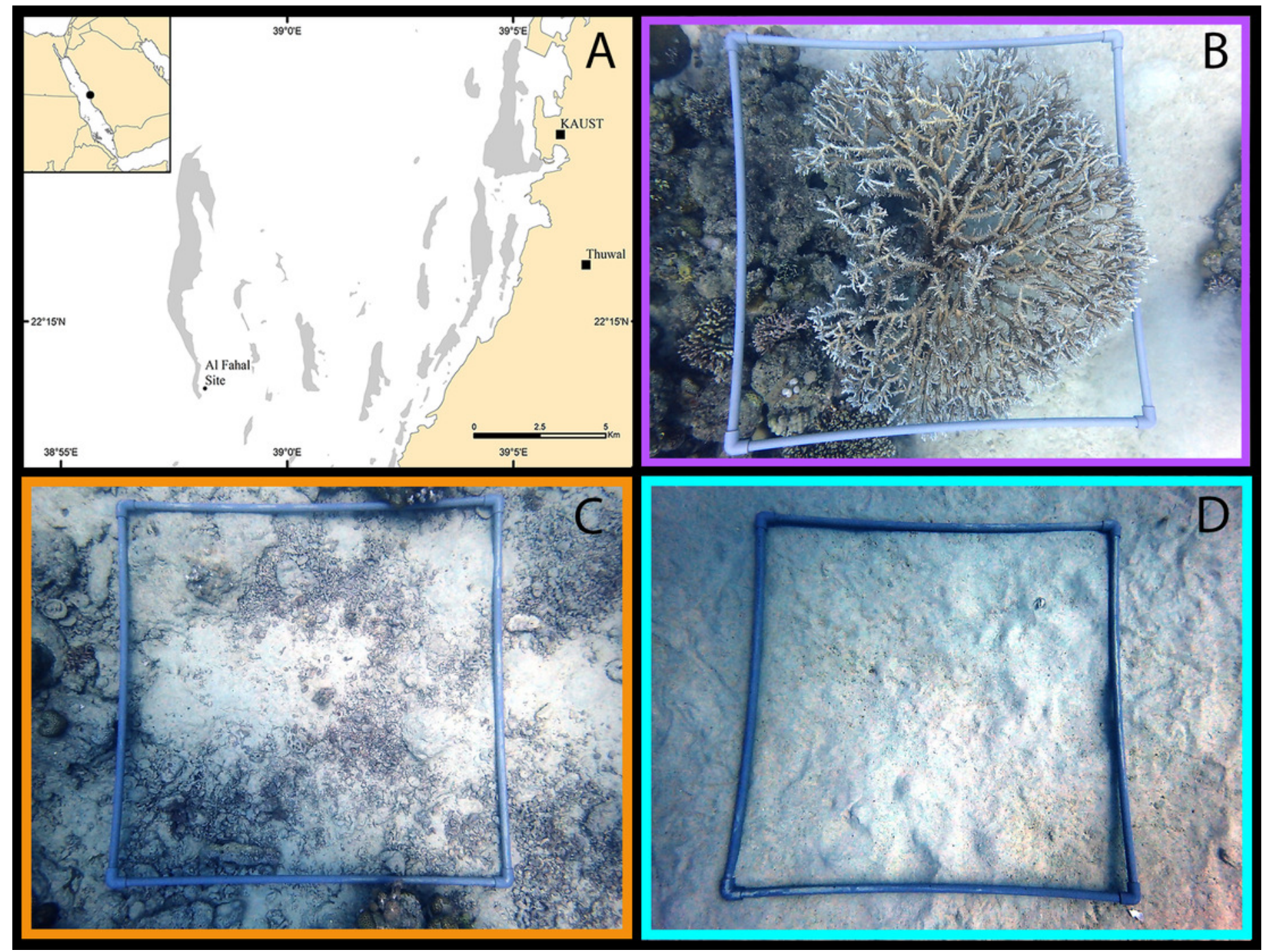




\section{Figure 2}

Fish community indices

Boxplots displaying abundance (number of individuals per $\mathrm{m}^{2}$ ), species richness (number of species per $\mathrm{m}^{2}$ ), and diversity $\left(\mathrm{H}^{\prime}\right)$ for all collected fishes and for family Gobiidae for each of the three microhabitat types sampled using rotenone stations ( $1 \mathrm{~m}^{2}$ quadrats, $\mathrm{n}=5$ quadrats per microhabitat type) in the central Saudi Arabian Red Sea. Asterisks denote significant pairwise groupings ( $* p<0.05, * * p<0.01, * * * p<0.001$ ). 


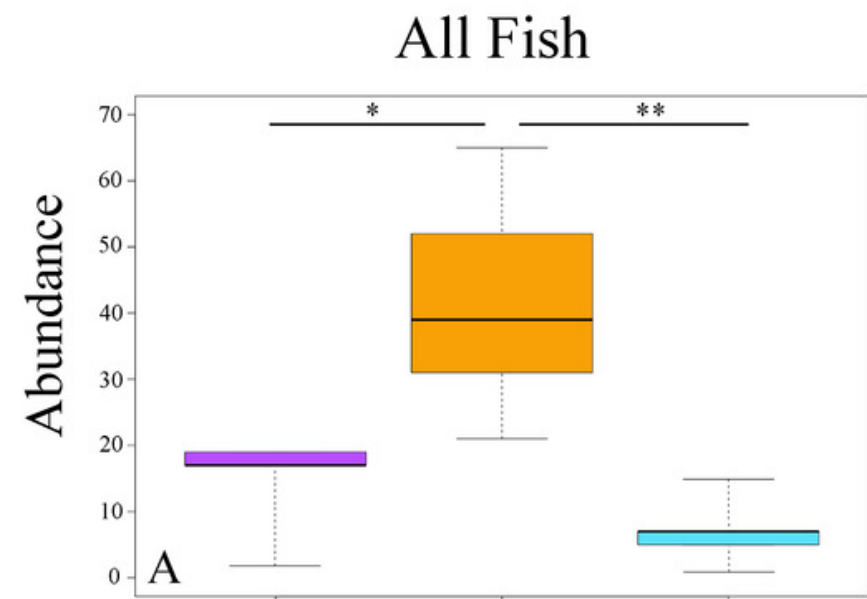

Gobiidae
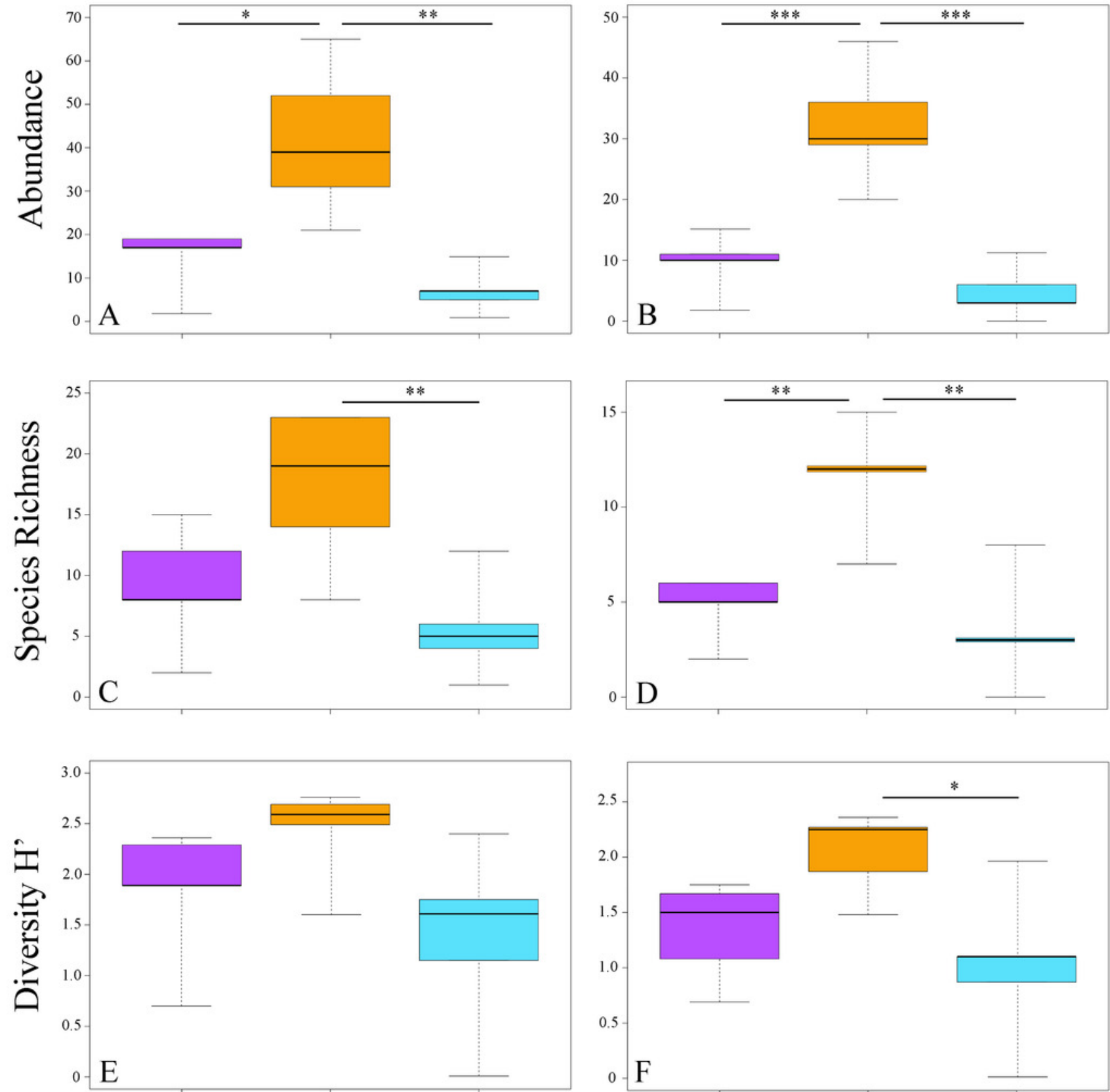

Coral $\odot$ Rubble $\bigcirc$ Sand 


\section{Figure 3}

Fish community similarities

nMDS plots using Bray-Curtis similarity and square root transformations of $A$ ) all fish

communities (i.e., relative abundances of all collected species) and B) goby communities (i.e., relative abundances of individuals from family Gobiidae) sampled using rotenone stations in each of the three microhabitat types in the central Saudi Arabian Red Sea. Solid points represent individual quadrats from each microhabitat type. Dendrograms of the hierarchical cluster analysis show habitat clustering for $\mathrm{C}$ ) all fish and D) gobies. Similar microhabitat communities are more closely clustered. (Note that quadrats Coral 4 and Sand 4 were excluded from the goby nMDS and dendrogram due to an absence of gobies in those quadrats). 

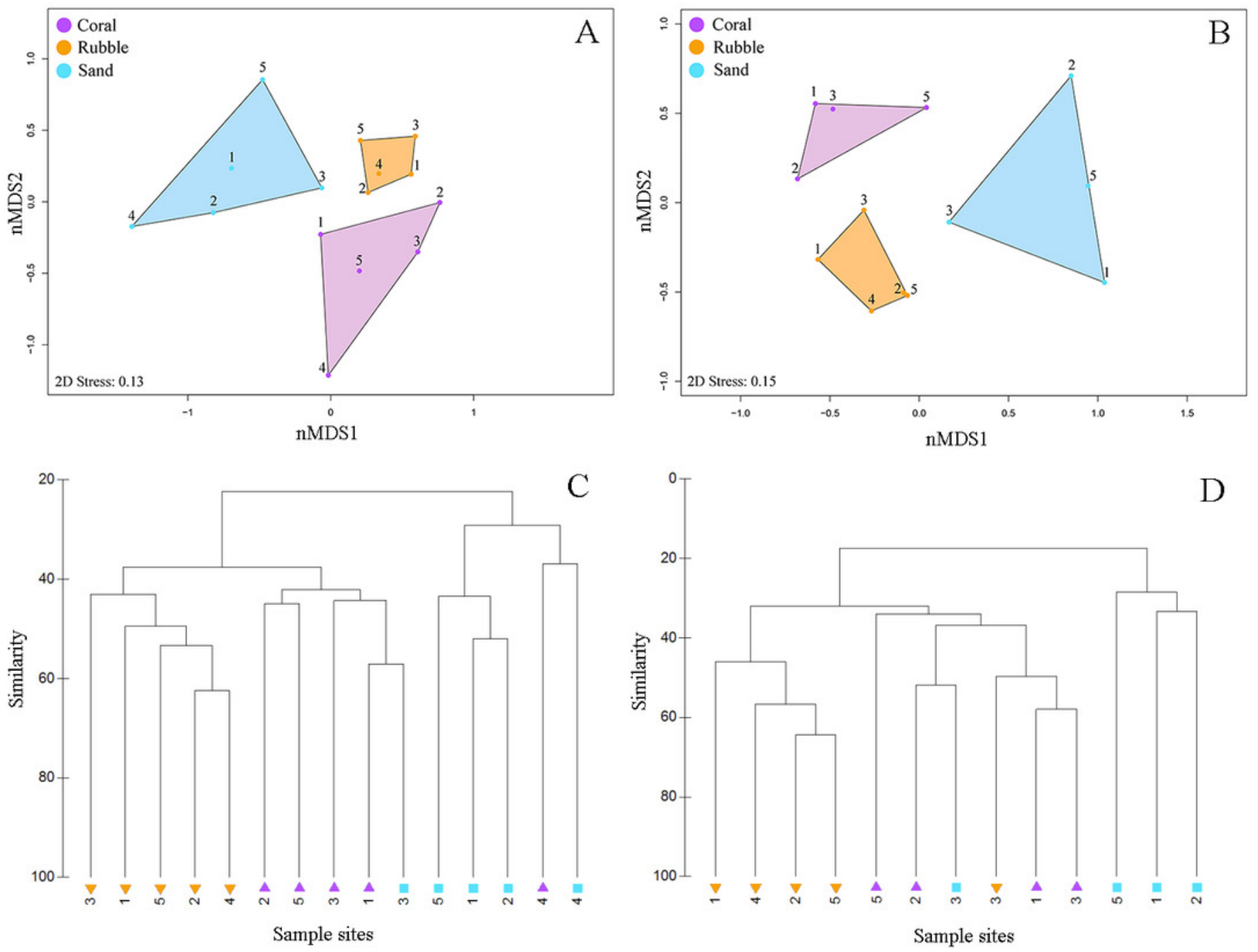


\section{Figure 4}

Goby species abundances

Rank-abundance plot of goby species sampled in the central Saudi Arabian Red Sea using 1 $\mathrm{m}^{2}$ rotenone stations in three microhabitat types. Vertical bars represent the total combined number of individuals sampled in all quadrats ( $n=5$ quadrats per microhabitat type) for all 31 goby species found in this study. Coloration of the vertical bars indicates the portion of individuals of each species found in the three microhabitat types.

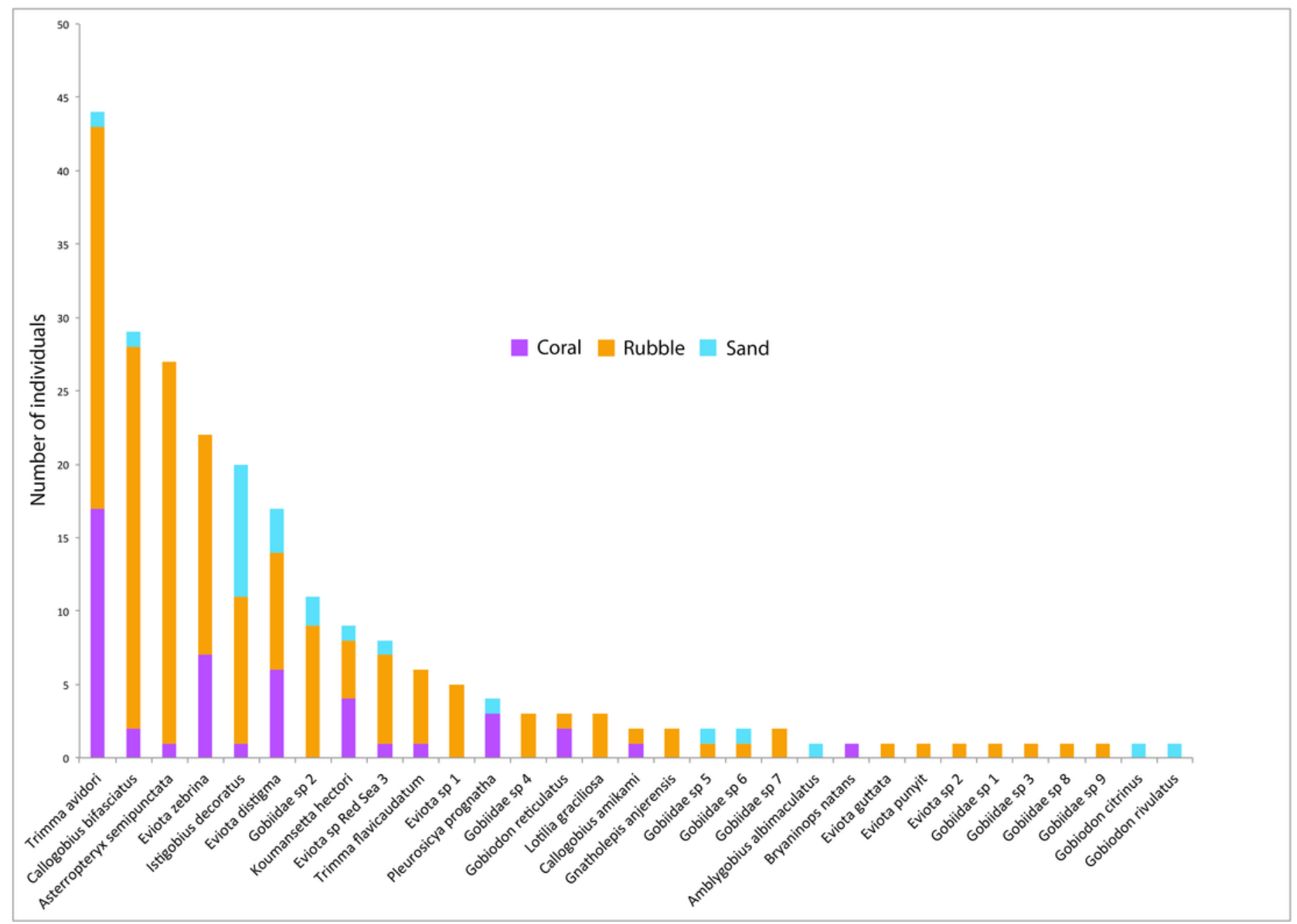




\section{Table $\mathbf{1}$ (on next page)}

Similarity percentage (SIMPER) analysis of all collected fish species

The average contribution of the top five species contributing most to the differences between microhabitat types is listed. Average abundance ( $1 \mathrm{~m}^{2}$ quadrats, $n=5$ quadrats per microhabitat type) is listed for each species collected from a reef in the central Saudi Arabian Red Sea. 
1

\begin{tabular}{|c|c|c|c|}
\hline \multicolumn{4}{|l|}{ Rubble vs. Sand } \\
\hline \multirow{2}{*}{ Species } & \multicolumn{2}{|c|}{ Average abundance } & \multirow{2}{*}{ Average Contribution (\%) } \\
\hline & Rubble & Sand & \\
\hline Callogobius bifasciatus & 5.2 & 0.2 & 12.58 \\
\hline Asterropteryx semipunctata & 5.2 & 0 & 12.53 \\
\hline Trimma avidori & 5.2 & 0.2 & 8.55 \\
\hline Eviota zebrina & 3 & 0 & 6.42 \\
\hline Istigobius decoratus & 2 & 1.8 & 3.37 \\
\hline \multicolumn{4}{|l|}{ Coral vs. Sand } \\
\hline \multirow{2}{*}{ Species } & \multicolumn{2}{|c|}{ Average abundance } & \multirow{2}{*}{ Average Contribution (\%) } \\
\hline & Coral & Sand & \\
\hline Pleurosicya prognatha & 2.8 & 0.2 & 10.94 \\
\hline Istigobius decoratus & 0.8 & 1.8 & 7.73 \\
\hline Trimma avidori & 1.4 & 0.2 & 5.77 \\
\hline Callionymidae sp. 1 & 0.2 & 1 & 5.65 \\
\hline Pseudochromidae sp. 2 & 1.2 & 0 & 5.17 \\
\hline \multicolumn{4}{|l|}{ Coral vs. Rubble } \\
\hline \multirow{2}{*}{ Species } & \multicolumn{2}{|c|}{ Average abundance } & \multirow{2}{*}{ Average Contribution (\%) } \\
\hline & Coral & Rubble & \\
\hline Asterropteryx semipunctata & 0.4 & 5.2 & 9.42 \\
\hline Callogobius bifasciatus & 1 & 5.2 & 8.83 \\
\hline Trimma avidori & 1.4 & 5.2 & 7.36 \\
\hline Eviota zebrina & 0.6 & 3 & 4.93 \\
\hline Pleurosicya prognatha & 2.8 & 0 & 4.66 \\
\hline
\end{tabular}

